stomach rejected it and those cases gave me a little trouble for a while. I believe your antiseptic treatment is the rational treatment for typhoid fever. Under its use the course of the disease is greatly modified; delirium is rare; tympanitis is prevented; the tongue remains moist through the illness; and the intestinal tract is placed in the best possible condition for the healing of the wounds. I am certainly thankful that I discovered your articles in the JoURnaL."

(To be continued.)

IS DIPHTHERIA DOOMED BY THE DISCOV. ERY OF ANTITOXIN?

Read before the Colorado State Medical Society, June 19, 1895.

BY F. E. WAXHAM, M.D.

NERITUE PROFESSOR OF LARYNGOLOGY AND RHINOLOGY, COLLEGE OF PHYSICIANS AND SIIRGEONS OF CHICAGO. DENVER, COLO.

Probably, with the exception of Koch's tuberculin, nothing has so interested and excited the civilized world as antitoxin, the new remedy for diphtheria. Like all other new advances and discoveries in medicine, it has its advocates who claim it as a specific when properly and timely used, also its enemies who decry its use and proclaim it a huge fraud; others again who admit the value of antitoxin but claim that its dangers more than offset its advantages; still again there are others, and among them Virchow, who acknowledge the dangers of the new remedy and yet claim that the lessened mortality under its use more than compensates for the dangers and risks of its employment. From all this conflicting testimony it is difficult to estimate its true value, but at present date the evidence is decidedly in its favor.

The opponents of antitoxin point to the anatomic lesions found in animals dying during immunization; the changes especially observed in the spleen, liver, kidneys and lymphatics, and also to certain symptoms obviously following the use of antitoxin, the most important being nephritis, skin eruptions, enlargement of lymphatic glands and occasional high and fluctuating temperature. They assert with much reason that antitoxin should prevent rather than produce these lesions and symptoms. They also deny the value of statistics and say that the lessened mortality is due to a lessened virulence of the epidemic at the time of observation rather than to any specific effect of antitoxin. The claim, therefore, that diphtheria is doomed by the discovery of this, one of the most remarkable remedial agents of the present century, can hardly be sustained. If diphtheria were doomed it should no longer exist in those centers of population where antitoxin and other means of controlling the disease are best known and most employed. Diphtheria should no longer exist in Berlin, Vienna and Paris, but on the contrary it is just as prevalent in these cities, although the fatalities may have been somewhat reduced, as before the discovery of antitoxin.

The three great scourges of the human race have been smallpox, tuberculosis and diphtheria; the greatest of all has been smallpox; whole countries time aud again have been ravaged and decimated by this disease, and yet while we have an almost certain preventive in vaccination, the disease has never been stamped out. Its ravages have been greatly lessened and an untold amount of suffering and death prevented, and yet the disease still remains and will continue as long as ignorance and superstition remain in the human breast. This being admittedly true of smallpox, with an almost unfailing and certain preventive, how much more true must it be of diphtheria, for which as yet we have no such panacea.

Antitoxin can in no way be compared to vaccination, for its effect is only temporary, lasting but a few weeks at most. Again, all cases of diphtheria are not applicable for treatment by antitoxin, and I submit that mild cases that would terminate favorably under ordinary treatment should not be subjected to the dangers of antitoxin treatment. Still, again, there are many cases, especially the mixed and septic cases, the most virulent and fatal, that are seemingly unaffected by this line of treatment.

Those who have followed closely the proceedings of the New York Academy of Medicine can not but be strongly prejudiced against antitoxin. Personally, I am convinced of the great value of this new remedy. I believe it is the best remedy that we possess in the treatment of a most dreaded disease, and yet I also believe that it has its limitations. Fancied security is often dangerous; to feel that diphtheria is doomed and that we have an unfailing remedy in antitoxin may lead us to overlook its dangers, to neglect sanitary measures, and to belittle other lines of treatment.

As cases at home are more interesting to us than cases reported at a distance, I beg to allude to the cases treated by antitoxin in Denver. These cases number twenty-one. Fourteen cases were treated by members of the antitoxin committee, appointed by the Arapahoe Medical Society, in conjunction with the attending physicians. Seven are reported to me by the Commissioner of Health, Dr. Munn, to whom I am under grateful obligation. Two cases were scarlatinal and should be excluded from the report, leaving nineteen cases, eighteen of which were proved to be true diphtheria by the bacteriologic examination, with three deaths.

The first death was in the case of an infant of nine months, suffering from surgical diphtheria following circumcision. Antitoxin was employed on the eighth day, and the patient died some five days later. The second case was an infant of seven months; antitoxin was used on the fifth day and the patient died one hour later. The third fatal case apparently recovered from the attack of diphtheria but died of pneumonia seven days after the introduction of the antitoxin. Whether the intercurrent pneumonia was due in any measure to the antitoxin treatment, I am unable to ascertain.

Admitting the value of antitoxin, believing in its efficacy as a most useful remedy, I would still assert that diphtheria is not yet doomed, but will still remain a most dreaded disease. Notwithstanding the new remedy, antitoxin, and its great value as a therapeutic agent, we will still have need of the most rigid sanitary precautions and preventive measures as isolation, disinfection and cleanliness. We shall still have need of all our resources, sanitary, medical and surgical.

One of the latest and most valuable contributions to the literature of antitoxin treatment of diphtheria has been written by Baginsky and Katz, of Berlin. After reporting a large number of cases treated, they conclude "that, while exerting a most favorable influence in the majority of the worst cases of diphtheria, yet antitoxin is by no means a cure all."

While expressing my conviction as to the great 
value of antitoxin, while acknowledging the indebtedness of humanity, for the long and patient and scientific investigations which have resulted in the production of one of the most wonderful remedial agents of the nineteenth century, yet $I$ submit that the affirmative side of this question remains to be proved, and that diph theria, while it may be mitigated and its perils and fatalities lessened, will yet still exist and will still continue to claim its victims.

\section{SOCIETY PROCEEDINGS.}

\section{American Electro-Therapeutic Association.}

Fourth Annual Meeting held in New York Academy of Medicine, New York, Sept. 25, 26 and 27, 1894.

William J. Herdman, M.D., President.

(Continued from page 204.)

A special report was presented by Dr. Robert Newman, on CONSTANT CURRENT GENERATORS AND CONTROLLERS.

The attention of manufacturers has been called to the circular of the Standing Committee concerning primary stationary batteries. Some have even received two or three communications, but out of all notified, the Leclanche Battery Co., and Vetter were the only ones who bave submitted their cells. But I have tested all which have come under my observation in other ways.

Some of the other battery companies have answered with the following results : Kidder Mfg. Co.says, "that we would be pleased to send you complete deseription of same-stationary battery-we fear their size would somewhat prevent their easy transportation." The primary batteries generating the current can be selected as to the wishes of the operator. The secondary batteries in preparation for test referred to Mr. Brown, of our committee.

Queen \& Co., Philadelphia, March 20,1894, that they " have nothing to submit for investigation." However, they advertise the Acme Portable Voltmeter, a new type for portable voltmeter for both alternating and direct current circuits. Why do they hold back the instrument if it is good?

The John L. Gish Ideal Rheostat Co., Jackson, Mich., March 25,1894 , that they have submitted their instruments to Dr. Herdman.

A portable alternating current-meter has been made by the General Electric Co.; it comes in 25 to 50 and 200 ampere sizes.

The result of batteries and cells investigated is as follows -Constant Current Batteries: Portable; Stationary.

The Vetter Dry Cell Portable Battery is a very complete one in itself, being nicely arranged and very convenient, having a milliampere meter attached and a rheostat. At first the battery worked very well and was thought to be a success-giving a soft even current-but after standing for a short time, on being tried, found scarcely any current at all. On a later trial found it to be in a much better condition. For a dry cell battery it is fair, but like them, can not be relied upon. If more electric power is needed, any number of wet cells may be added by attaching the extra cells to a wire on the case.

My assistant reports on the battery as follows: "The Vetter Dry Cell Battery I tested and found I could get just $1 / 2$ milliampere with the 30 measure and 50 milliamperes with the 300 measure using a closed circuit of cord. I took the instrument to pieces and found six or seven cells badly corroded and so, of course, it would work but little. The machine has been carefully handled and I see no reason for finding the instrument in the condition I did, if it only corrodes on being short circuited, which it has not to my knowledge, I being the only one using it. However, that is the condition I find, and it needs some new cells."

The Vetter is a nice piece of workmanship and is complete as a portable battery, but my experience is that dry cells are not reliable and the worst of all are the dry chlorid of silver cells with which I have had my worst experience.

Dry Chlorid of Silver Cell. I had a $50 \mathrm{dry}$ cell Chlorid of Silver Battery on which the pole $P$, marked as positive was, on investigation, found to be the negative; notwithstanding my protest, the manufacturers insisted they were right. At last the error was acknowledged in a communication, Nov.
16,1891 , and the battery came back from the factory in Baltimore-the P.altered into an $\mathrm{N}$.

After a 50 dry cell galvanic battery had been put in thorough order in Baltimore, I left it standing as peceived and later on, in a trial, found it would give no current at all. The battery was sent back to the factory and the manager acknowledging the inactivity only said: "It must have been used on short circuit"-and no redress given. I never received the battery back and lost it. I consider there is no reliance in a dry cell chlorid of silver battery; the E. M. F. is small and insufficient for electrolysis.

Stationary Batteries: the Waite \& Bartlett, cabinet, galvanic and faradic; 40 cells-Ieclanche cells.

Run from November, 1888, for three years until the end of 1891 , in perfect order. Was used every day, often for hours, but mostly with light current. After three years constant use the cells were only filled and somewhat overhauled. In November, 1893, after five years, the cells were thoroughly repaired and new zincs put in. The cabinet is very convenient, easily handled while sitting, has reverser, interrupter, resistance and faradic battery. Milliampere meter is attached on top of case. I consider this cabinet most convenient for my use.

The measurement of cells has been made and reported on last year by Dr. Herdman as chairman of this committee with such care and accuracy, that scarcely any thing more or better can be added. My own experiments as far as I could pursue the same without the necessary facilities and laboratory confirm Dr. Herdman's measures, and the following is only reported here by order of the chairman of this committee, serving as a supplementary report.

Generating cells-axo cells. (Leclanche Battery Co.) I have now in use the axo cells made by the Leclanche Battery Co., 111 to 117 E. 131st Street, New York, in both my Providence and New York office, which has given entire satisfaction for medical work. The axo has all the advantages of a sealed cell. The flange of the cup closes the jar and prevents evaporation, so that, when once put up, with care the cells may run almost a year without any attention. At the same time there is sufficient room for the escape of gases through grooves in the sides of the carbon. The electromotor force is 1.60 . The internal resistance is $1 \mathrm{ohm}$.

Closed circuit measurements of one cell through the Whitney volt meter and Whitney ampere meter.

Fole Cell. (Ieclanche Battery Co.) Warner gage 36 ; voltage 1.52 ; ampèrage 2.2

Gonda Cell. (Leclanche Battery Co.) Warner gage 26.5; voltage 1.5 ; amperage 1.95 .

Sampson Cell. Warner gage $26 . \overline{\text {; }}$ voltage 1.4 ; amperage 4 .

Law Cell. (Regular.) Warner gage 7.5 ; voltage 0.9 ; ampèrage 2.9 .

Mesco Dry Cell. Warner gage 17.5 ; voltage 1.4 ; ampèrage 2.

Edison-Laland Cells. Providence, R. I., Feb. 1, 1894. Present, Newman and C. E. Bourn. Six large Edison cells for galvano-cautery. Room 68 degrees F,, 9 o'clock, A.M, Weston A. M. meter.

Rheostat in, gave 4 ampères. Rbeostat all out, full current and strength of battery $83 / 4$ amperes. Rheostat in to onehalf, 5 amperes. Rheostat in $31 / 2$ ampères. Hence polarization. Jan. 18, 1894, 11 A.M. 'The same Edison cells-six-for galvano-cautery in series. Present, Mr. Hughes, C. E. Bourn and Newnan. Weston's voltmeter. 3 cells in front ; 2.75 volts; 3 cells in back rcw 2.75 volts; 6 cells together 5.14 volts. Temperature of room 63 degrees F.

Edison Small Cells. 50 cells galvanic battery. 25 cells, 22 volts; 25 cells (other), 22 volts; 50 cells (all), 44 volts.

Feb. 1, 1894, 10 A.x., room 70 degrees F. Weston's A. M. meter; 50 cells, Edison galvanic battery, 1 ampere. 40 cells, low tension gravity cells. Weston's A.M. meter $1 / 2$ ampere. Jan. 18, 1894, Weston's voltmeter 33 volts.

The Wottin Transformer has to be investigated. Has been sent to Dr. Herdman. On an alternating current of 52 volts. It can be made for the Edison street current of 110 volts. They have no meter to measure. June 15,1894 . It heated all my platinum burners, some very heavy ones, made for testing more than for therapeutic use. It also heated well my galvano-cautery sound. It can be used nicely for iiluminating. It will light two incandescent lamps, and at the same time run two fans or drills where the motors are suitable, and still supply the transformer.

Rheostat and Controllers, etc. The Vetter Rheostat is a very good instrument when weak currents are used. I have not found a better one. However, the disadvantages are, that at strong currents it may burn out; that on looking at $i^{t}$ you never know if the rheostat is off or on. It must be 